\title{
HUBUNGAN SANITASI LINGKUNGAN SEKOLAH DASAR DENGAN KEJADIAN DEMAM BERDARAH DENGUE DI KECAMATAN CANDI KABUPATEN SIDOARJO
}

\author{
Nirmala Tri Kartika \\ Supriyadi \\ Agung Kurniawan \\ Fakultas Ilmu Keolahragaan Universitas Negeri Malang \\ email: ntkartika@gmail.com
}

\begin{abstract}
Dengue hemorrhagic fever (DHF) has increased every year. The DHF case ini Sidoarjo district has increased in 3 years. The case was experienced by many children of primary school age. One factor that can increase the risk of this disease is the environmental sanitation of the school. The study aims to determine the relationship between environmental sanitation of elementary school with the incidence of dengue in the Candi subdistrict, Sidoarjo. This type of research is Analytical Survey. The study population is 29 state elementary schools in Candi subdistrict, Sidoarjo. Samplers using cluster random sampling technique, that obtained 24 schools. Collecting data used for the assessment from Health Office of Sidoarjo District. Analysis of data is used statistical test of Rank Spearman. Based on the study results showed that there is no significant relationship between elementary schools environmental sanitation with the incidence of dengue hemorrhagic fever $(0,570>$ 0,05), with the translation of sub variables studied as follows: there is no significant relationship between the availability of clean water to the incidence of dengue fever dengue (0,293>0,05), there is no significant relationship between the means of waste disposal with the incidence of dengue hemorrhagic fever $(0,729>0,05)$, and no significant correlation between the density of mosquito larvae with the incidence of dengue hemorrhagic fever $(0,031$ $<0,05)$. The conclusion of this study is there is no relationship between the school environmental sanitation, sub variable of water supply and waste disposal facilities with the incidence of dengue fever. There is a relationship between sub variable density of mosquito larvae with.
\end{abstract}

Keywords: school environmental sanitation, dengue fever, Sidoarjo

\begin{abstract}
Abstrak: Penyakit demam berdarah dengue (DBD) mengalami peningkatan setiap tahunnya. Kabupaten Sidoarjo mengalami peningkatan selama 3 tahun terakhir. Kasus tersebut banyak dialami oleh anak usia sekolah dasar. Salah satu faktor yang dapat meningkatkan resiko penyakit ini ialah sanitasi lingkungan sekolah. Penelitian bertujuan untuk mengetahui hubungan sanitasi lingkungan sekolah dasar dengan kejadian demam berdarah dengue di Kecamatan Candi Kabupaten Sidoarjo. Jenis penelitian yang digunakan adalah Survei Analitik. Populasi penelitian ini adalah semua Sekolah Dasar Negeri di Kecamatan Candi Kabupaten Siodarjo yang berjumlah 29 sekolah, pengambil sampel dengan menggunakan teknik cluster random sampling, diperoleh jumlah sampel, yaitu 24 sekolah. Pengumpulan data menggunakan format penilaian dari Dinas Kesehatan Kabupaten Siodarjo. Analisis data menggunakan uji statistik Rank Spearman. Berdasarkan hasil Penelitian menunjukkan bahwa tidak ada hubungan yang signifikan antara sanitasi lingkungan sekolah dasar dengan kejadian demam berdarah dengue $(0,570>0,05)$, dengan penjabaran sub variabel yang diteliti sebagai berikut: tidak ada hubungan yang signifikan antara ketersedian air bersih dengan kejadian demam berdarah dengue $(0,293>0,05)$, tidak ada hubungan yang signifikan antara sarana pembuangan sampah dengan kejadian demam berdarah dengue $(0,729>0,05)$, dan ada hubungan yang signifikan antara kepadatan jentik nyamuk dengan kejadian demam berdarah dengue $(0,031<0,05)$. Kesimpulan dari penelitian ini adalah tidak ada hubungan antara sanitasi lingkungan sekolah, sub variabel ketersediaan air bersih dan sub variabel sarana pembuangan sampah dengan kejadian demam berdarah dengue. Ada hubungan antara sub variabel kepadatan jentik nyamuk dengan kejadian demam berdarah dengue.
\end{abstract}

Kata kunci: sanitasi lingkungan sekolah, demam berdarah dengue, Sidoarjo 
Kabupaten Sidoarjo merupakan salah satu daerah endemis di Provinsi Jawa Timur yang setiap tahun selalu terdapat kasus DBD dan kematian karena penyakit tersebut. Data kasus DBD dari Dinas Kesehatan Kabupaten Sidoarjo pada tahun 2014 sampai dengan Agustus 2016 mengalami peningkatan. Pada tahun 2014 terjadi 171 kasus dengan incident rate (IR) sebesar 8,1/100.000 penduduk dan case fatality rate (CFR) sebesar 0,6\% (Dinas Kesehatan Kabupaten Sidoarjo, 2015). Pada tahun 2015 terjadi 601 kasus dengan IR 28,3/100.000 penduduk dan CFR sebesar 4,8\% (Dinas Kesehatan Kabupaten Sidoarjo, 2016). Data DBD hingga Agustus 2016 terjadi 1.279 kasus dengan CFR sebesar 2,6\% (Dinas Kesehatan Kabupaten Sidoarjo, 2016).

Kecamatan Candi merupakan Kecamatan di Kabupaten Sidoarjo yang memiliki kasus DBD paling tinggi, tahun 2015 terdapat 57 kasus dan pada JanuariAgustus 2016 terdapat 155 kasus (Dinas Kesehatan Kabupaten Sidoarjo, 2016). Peningkatan kasus DBD di Kabupaten Sidoarjo dialami oleh anak-anak usia Sekolah Dasar (5-12 tahun). Pada tahun 2015 terdapat 264 anak yang terkena DBD dari 601 kasus dan pada bulan Januari sampai dengan Agustus 2016 terdapat 607 anak yang terkena DBD dari 1.279 kasus. Sekolah dapat menjadi tempat yang potensial dalam penyebaran dan penularan penyakit DBD pada anak sekolah, hal ini dikarenakan nyamuk Aedes aegypti secara alamiah bersifat multiple bitter (mengisap darah berpindah-pindah dan berkali-kali) serta aktif menggigit pada pagi hari (jam 08.00-10.00) bersama dengan aktivitas anak sekolah belajar di kelas (Departemen Kesehatan Republik Indonesia dalam Nurjanah, 2013). Salah satu faktor yang meningkatkan resiko terjadinya penyebaran dan penularan penyakit DBD pada anak di lingkungan sekolah adalah sanitasi lingkungan. Menurut Elder dan Lloyd (dalam Hariyono, 2016) menyatakan bahwa peningkatan kasus DBD terkait erat dengan sanitasi lingkungan yang buruk. Hasil penelitian yang dilakukan oleh Sholihah dan Prasetyo (2014) diketahui bahwa sanitasi lingkungan yang berpengaruh terhadap kejadian DBD ialah kontainer, ventilasi, dan pengetahuan tentang DBD. Sedangkan hasil penelitian yang dilakukan oleh Suyasa dkk (2008) diketahui bahwa sanitasi lingkungan yang berpengaruh terhadap kejadian DBD ialah keberadaan vektor DBD, kepadatan penduduk, mobilitas penduduk, keberadaan tempat ibadah, keberadaan pot tanaman hias, keberadaan saluran air hujan dan keberadaan.

Berdasarkan pemaparan diatas peneliti bertujuan meneliti hubungan sanitasi lingkungan sekolah dasar, ketersediaan air bersih, saranan pembuangan sampah, dan kepadatan jentik nyamuk dengan kejadian demam berdarah dengue.

\section{METODE}

Desain penelitian yang digunakan adalah deskriptif analitik dengan menggunakan cross sectional. Jumlah populasi dalam penelitian ini sebanyak 29 Sekolah Dasar Negeri (SDN) dengan teknik sampling yang digumakan cluster random sampling, sehingga sampel pada penelitian ini menjadi 24 SDN. Instrumen penelitian yang digunakan berupa dokumentasi kasus demam bedarah dengue tahun 2015hingga Agustus tahun 2016 dan format penilaian sanitasi lingkungan sekolah dasar dariDinas Kesehatan Kabupaten Sidoarjo.Penelitian ini dilaksanakan di Sekolah Dasar Negeri Kecamatan Candi Kabupaten Sidoarjo selama 1 bulan, yaitu bulan NovemberDesember 2016. Pengumpulan data dilakukan dengan observasi menggunakan format penilaian hygiene sanitasi SD/MI dan dokumentasi kasus DBD di setiap sekolah. Analisis data yang digunakan ialah analisis deskriptif dan analisis korelasi (Uji Statistika Spearman) dengan aplikasi SPSS v.22. 


\section{HASIL}

Tabel 1. Hasil data analisis deskriptif dari variabel sanitasi lingkungan sekolah dasar dan kejadian DBD serta sub variabel ketersediaan air bersih, sarana pembuangan sampah, kepadatan jentik nyamuk.

\begin{tabular}{llll}
\hline & Min & Max & Mean \\
\hline Sanitasi lingkungan sekolah dasar & 65,67 & 100,86 & 80,68 \\
Ketersediaan air bersih & 21 & 49 & 37,04 \\
Sarana pembuangan sampah & 28 & 56 & 40,83 \\
Kepadatan jentik nyamuk & 2 & 4 & 2,81 \\
Kejadian dbd & 2 & 30 & 6,50 \\
\hline
\end{tabular}

Pada tabel diatas diketahui bahwa variabel sanitasi lingkungan sekolah dasar memiliki skor terendah (minimum) sebesar 65,67 yaitu SDN Durungbanjar, SDN Durungbedug dan SDN Balongdowo, skor tertinggi (maximum) sebesar 100,86 yaitu SDN Gelam II dan skor rata-rata sebesar 80,67. Pada sub variabel ketersediaan air bersih memiliki skor terendah sebesar 21 yaitu SDN Kedungpeluk I dan skor tertinggi sebesar 49 yaitu SDN Larangan dan SDN Sumorame dari total skor 70 dengan skor rata-rata sebesar 37,04. Pada sub variabel sarana pembuangan sampah skor terendah sebesar 28 yaitu SDN Durungbanjar, SDN Balongdowo, dan
SDN Balonggabus dan skor tertinggi sebesar 56 yaitu SDN Gelam II dan SDN Sugihwaras dari total skor 70 dengan skor rata-rata sebesar 40,83. Pada sub variabel kepadatan jentik nyamuk skor terendah sebesar 2 yaitu SDN Larangan dan skor tertinggi sebesar 4 yaitu SDN Kedungpeluk I dengan skor rata-rata sebesar 2,81. Terakhir, pada variabel kejadian DBD diketahui bahwa sekolah yang memiliki kejadian terendah yaitu SDN Larangan dan SDN Sugihwaras dengan 2 kejadian dan kejadian tertinggi sebesar 30 kejadian yaitu SDN Ngampelsari.

Tabel 2. Uji normalitas variabel sanitasi lingkungan sekolah dasar dan kejadian DBD

\begin{tabular}{lll}
\hline & Shapiro Wilk & \\
\cline { 2 - 3 } & $\boldsymbol{d}$ f & Sig. \\
\hline Sanitasi lingkungan sekolah dasar & 24 & 0,008 \\
Kejadian DBD & 24 & 0,000 \\
\hline
\end{tabular}

Pada tabel uji normalitas diketahui bahwa jumlah data yang di uji 24 sample sehingga menggunakan uji normalitas Shapiro-Wilk. Pada uji normalitas sanitasi lingkungan sekolah dasar diketahui nilai
Sig. $<\alpha(0,008<0,05)$ sehingga data dikatakan tidak normal dan pada uji normalitas kejadian DBD diketahui nilai Sig. $<\alpha(0,000<0,05)$ sehingga data dikatakan tidak normal. 
Tabel 3. Uji normalitas sub variabel ketersediaan air bersih, sarana pembuangan sampah, dan kepadatan jentik nyamuk.

\begin{tabular}{lll}
\hline & Shapiro Wilk & \\
\cline { 2 - 3 } & df & Sig. \\
\hline Ketersediaan air bersih & 24 & 0,027 \\
Sarana pembuangan sampah & 24 & 0,037 \\
Kepadatan jentik nyamuk & 24 & 0,017 \\
\hline
\end{tabular}

Pada uji normalitas ketersediaan air bersih diketahui nilai Sig. $<\alpha$ $(0,027<0,05)$ sehingga data ketersediaan air bersih dikatakan tidak normal, uji normalitas sarana pembuangan sampah diketahui nilai Sig. $<\alpha \quad(0,037<0,05)$ sehingga data sarana pembuangan sampah dikatakan tidak normal, dan uji normalitas kepadatan jentik nyamuk diketahui nilai Sig. $<\alpha$ $(0,017<0,05)$ sehingga data kepadatan jentik nyamuk dikatakan tidak normal.

Tabel 4. Hubungan sanitasi lingkungan sekolah dasar dengan kejadian demam berdarah dengue (DBD)

\begin{tabular}{|c|c|c|c|}
\hline & & & Sanitasi lingkungan sekolah dasar \\
\hline Spearman's & & Correlation coefficient & -0.122 \\
\hline rho & DBD & $\begin{array}{l}\text { Sig. (2-tailed) } \\
\mathrm{N}\end{array}$ & $\begin{array}{l}0,570 \\
24\end{array}$ \\
\hline
\end{tabular}

Berdasarkan tabel di atas diketahui koefisien korelasi sebesar $-0,122$ dan nilai Sig. $>\alpha(0,570>0,05)$ sehingga dapat disimpulkan bahwa tidak terdapat hubungan yang signifikan antara sanitasi lingkungan sekolah dasar dengan kejadian demam berdarah dengue.
Tanda negatif pada koefisien korelasi menunjukkan korelasi yang terjadi antara sanitasi lingkungan sekolah dasar dengan demam berdarah dengue tidak berbanding lurus, yang artinya semakin baik sanitasi lingkungan sekolah dasar, maka tidak semakin berkurang kejadian DBD di sekolah tersebut.

Tabel 5. Hubungan ketersediaan air bersih dengan kejadian demam berdarah dengue (DBD)

\begin{tabular}{|c|c|c|c|}
\hline \multirow{3}{*}{ Spearman's } & & & Ketersediaan air bersih \\
\hline & & Correlation coefficient & $-0,224$ \\
\hline & DBD & $\begin{array}{l}\text { Sig. (2-tailed) } \\
\mathrm{N}\end{array}$ & $\begin{array}{l}0,293 \\
24\end{array}$ \\
\hline
\end{tabular}

Berdasarkan tabel di atas diketahui koefisien korelasi sebesar -0,224 dan nilai Sig. $>\alpha(0,293>0,05)$ sehingga dapat disimpulkan bahwa tidak terdapat hubungan yang signifikan antara ketersediaan air bersih dengan kejadian demam berdarah dengue.
Tanda negatif pada koefisien korelasi menunjukkan korelasi yang terjadi antara ketersediaan air bersih dengan demam berdarah dengue tidak berbanding lurus, yang artinya semakin baik akses air bersih yang ada, maka tidak semakin berkurang kejadian DBD di sekolah tersebut. 
Tabel 6. Hubungan sarana pembuangan sampah dengan kejadian demam berdarah dengue (DBD)

\begin{tabular}{|c|c|c|c|}
\hline \multirow{3}{*}{$\begin{array}{l}\text { Spearman's } \\
\text { rho }\end{array}$} & & & Sarana pembuangan sampah \\
\hline & & Correlation coefficient & $-0,075$ \\
\hline & DBD & $\begin{array}{l}\text { Sig. (2-tailed) } \\
\mathrm{N}\end{array}$ & $\begin{array}{l}0,729 \\
24\end{array}$ \\
\hline
\end{tabular}

Berdasarkan tabel di atas diketahui koefisien korelasi sebesar - 0,075 dan nilai Sig. $>\alpha(0,729>0,05)$ sehingga dapat disimpulkan bahwa tidak terdapat hubungan yang signifikan antara sarana pembuangan sampah dengan kejadian demam berdarah dengue.
Tanda negatif pada koefisien korelasi menunjukkan korelasi yang terjadi antara sarana pembuangan sampah dengan demam berdarah dengue tidak berbanding lurus, yang artinya semakin baik pengelolaan sampah yang dilakukan, maka tidak semakin berkurang kejadian DBD tersebut.

Tabel 7. Hubungan kepadatan jentik nyamuk dengan kejadian demam berdarah dengue (DBD)

\begin{tabular}{lll}
\hline & & Kepadatan jentik nyamuk \\
\hline \multirow{3}{*}{ Spearman's rho DBD } & Correlation coefficient & $-0,441$ \\
& Sig. (2-tailed) & 0,031 \\
& $\mathrm{~N}$ & 24 \\
\hline
\end{tabular}

Berdasarkan tabel di atas diketahui koefisien korelasi sebesar 0,441 dan nilai Sig. $<\alpha(0,031<0,05)$ sehingga dapat disimpulkan bahwa terdapat

hubungan yang signifikan antara kepadatan jentik nyamuk dengan kejadian demam berdarah dengue.

Tanda positif pada koefisien korelasi menunjukkan korelasi yang terjadi antara kepadatan jentik nyamuk dengan demam berdarah dengue berbanding lurus, yang artinya semakin tinggi kepadatan jentik nyamuk, maka semakin tinggi pula kejadian DBD di sekolah tersebut.

\section{PEMBAHASAN}

Hubungan sanitasi lingkungan sekolah dengan kejadian demam berdarah dengue

Hasil penelitian menunjukkan bahwa tidak terdapat hubungan yang signifikan antara sanitasi lingkungan sekolah dasar dengan kejadian demam berdarah dengue. Hal ini tidak sejalan dengan penelitian yang dilakukan oleh
Sholihah dan Prasetyo (2014) yang menyatakan bahwa ada hubungan yang signifikan antara kondisi sanitasi lingkungan dengan kejadian DBD di Kelurahan Lontar.Tidak adanya hubungan ini dikarenakan hasil observasi dengan menggunakan format penilaian sanitasi lingkungan sekolah dasar dan kemudian diklasifikasikan menurut kategorinya, menyatakan bahwa sanitasi lingkungan di semua Sekolah Dasar Kecamatan Candi Kabupaten Sidoarjo termasuk dalam katergori cukup baik, hanya SDN Gelam II yang termasuk kategori baik.

\section{Hubungan ketersediaan air bersih dengan kejadian demam berdarah dengue}

Hasil penelitian menunjukkan bahwa tidak ada hubungan yang signifikan antara ketersediaan air bersih dengan kejadian DBD. Hal ini juga didukung oleh hasil penelitian yang dilakukan oleh Nurjanah dkk (2008) yang menyatakan bahwa tidak ada hubungan yang bermakna 
antara akses terhadap air bersih dengan kejadian DBD, dan penelitian yang

dilakukan oleh Wahyuni (2013) menyatakan bahwa penyediaan air bersih bukan merupakan faktor resiko dari penyakit demam berdarah, melainkan merupakan faktor pendukung kejadian DBD.

Tidak adanya hubungan antara ketersediaan air bersih dengan kejadian DBD dapat dipengaruhi oleh variabel intervening, yaitu penyimpanan air bersih. Penelitian yang dilakukan oleh Hasyimi dan Soekino (2004) menjelaskan bahwa wilayah yang penyediaan airnya tidak teratur, memiliki perilaku menyimpan air sehingga hal ini juga berpotensi sebagai tempat perindukan nyamuk vektor DBD. Selain itu WHO (dalam Wahyuni, 2013) menyatakan bahwa dengan simpanan air ini timbul bersamaan masalah perkembangbiakan Aedes aegypti dan peningkatan resiko infeksi virus dengue.

Dari 6 sekolah di wilayah Kecamatan Candi yang dekat dengan perkotaan, 4 sekolah tidak mengalami kesulitan dalam mengakses air bersih sehingga tidak melakukan penyimpanan air. Namun, Sekolah yang kesulitan dalam memperoleh air bersih terutama di wilayah pedesaan, juga tidak melakukan penyimpanan air, sehingga mengurangi resiko perkembangbiakan nyamuk Aedes aegypti. Hanya 7 sekolah yang melakukan penyimpanan air bersih di wilayah ini dikarenakan jumlah siswa yang banyak. Sekolah-sekolah tersebut ialah SDN Sumokali, SDN Bligo, Kedungpeluk I, SDN Kendalpecabean, SDN Candi, SDN Balongdowo, dan SDN Balonggabus.

\section{Hubungan sarana pembuangan sampah dengan kejadian demam berdarah dengue}

Hasil penelitian menunjukkan bahwa tidak ada hubungan yang signifikan antara sarana pembuangan sampah dengan kejadian. Hal ini didukung oleh hasil penelitian Suyasa dkk (2008) yang menyatakan tidak ada hubungan antara keberadaan tempat sampah dengan keberadaan vektor DBD. Penelitian yang dilakukan oleh Wahyuni (2013) menyatakan bahwa yaitu pengelolaan sampah bukan merupakan faktor resiko dari penyakit demam berdarah, melainkan merupakan faktor pendukung kejadian DBD.

Tidak adanya hubungan antara sarana pembuangan sampah dengan kejadian DBD ini sama halnya dengan ketersediaan air, yaitu dapat dipengaruhi oleh variabel intervening. Dalam hal ini yaitu pengolahan sampah. Nurjanah dkk (2008) menyatakan bahwa keberadaan sampah di lingkungan sekolah seperti plastik bekas makanan maupun botol bekas menjadi hal yang harus diperhatikan karena akan berkontribusi sebagai tempat perkembangbiakan nyamuk Aedes aegypti. Selain itu sampah padat yang berserakan harus dibuang dan dikubur di tempat penimbunan sampah (WHO, 2004)

Sebagian besar Sekolah Dasar di Kecamatan Candi Kabupaten Sidoarjo sudah memiliki tempat sampah yang sesuai, seperti adanya tutup tempat sampah dan tempat sampah yang terpisah antara yang kering dan basah atau yang organik dan anorganik. Pada proses pemusnahan sampah, sebagian besar sekolah melakukannya dengan membakar dan itu dilakukan setiap hari setelah kegiatan pembelajaran selesai, kecuali SDN Candi dan SDN Kedung Peluk I

yang sampahnya diangkut oleh masyarakat desa untuk dibuang ke tempat pembuangan akhir.

\section{Hubungan kepadatan jentik nyamuk dengan kejadian demam berdarah dengue}

Hasil penelitian menunjukkan bahwa ada hubungan yang signifikan antara kepadatan jentik nyamuk (bebas jentik nyamuk) dengan kejadian DBD. Hal ini didukung oleh hasil penelitian yang dilakukan oleh Suyasa (2008) 
menyatakan bahwa ada hubungan antara keberadaan kontainer dengan keberadaan vektor DBD. Hasil penelitian yang dilakukan Wati (2010) maupun Sucipto (2015) menyatakan hal yang sama yaitu terdapat hubungan yang signifikan antara tempat penampungan air yang terdapat jentik dengan kejadian DBD.

Penelitian tersebut disebabkan karena belum maksimalnya program Pemberantasan Sarang Nyamuk (PSN) 3M plus di lingkungan sekolah sehingga rantai perkembangbiakan nyamuk bisa berlangsung sampai nyamuk dewasa. Kegiatan 3M plus sendiri diantaranya (Kementerian Kesehatan RI, 2016):

1. Menguras, adalah membersihkan tempat yang sering dijadikan tempat penampungan air seperti bak mandi, ember air, tempat penampungan air minum, penampung air lemari es dan lain-lain,

2. Menutup, yaitu menutup rapat-rapat tempat-tempat penampungan air seperti drum, kendi, toren air, dan lain sebagainya, dan

3. Memanfaatkan kembali atau mendaur ulang barang bekas yang memiliki potensiuntukjaditempat

perkembangbiakan nyamuk penular DBD.

Adapun yang dimaksud dengan plus ialah menaburkan bubuk larvasida pada tempat penampungan air yang sulit dibersihkan, menggunakan obat nyamuk atau anti nyamuk, memelihara ikan pemangsa jentik nyamuk, menanam tanaman pengusir nyamuk, mengatur cahaya dan ventilasi dan lain-lain.

Keberadaan jentik nyamuk yang hidup di berbagai tempat penampungan air seperti bak mandi, genangan air di wastafel maupun genangan air ditempat lainnya sangat memungkinkan terjadinya demam berdarah dengue dan apabila dibiarkan maka kejadian DBD akan terus meningkat.

\section{KESIMPULAN}

Berdasarkan hasil penelitian mengenai hubungan sanitasi lingkungan sekolah dasar dengan kejadian demam berdarah dengue di Kecamatan Candi Kabupaten Sidoarjo dapat diperoleh kesimpulan sebagai berikut.

1. Tidak ada hubungan antara sanitasi lingkungan sekolah dasr dengan kejadian demam berdarah dengue di Kecamatan Candi Kabupaten Sidoarjo

2. Tidak ada hubungan antara ketersediaan air bersih dengan kejadian demam berdarah dengue di Kecamatan Candi Kabupaten Sidoarjo

3. Tidak hubungan antara sarana pembuangan sampah dengan kejadian demam berdarah dengue di Kecamatan Candi Kabupaten Sidoarjo

4. Ada hubungan antara kepadatan jentik nyamuk dengan kejadian demam berdarah dengue di Kecamatan Candi Kabupaten Sidoarjo

\section{SARAN}

Berdasarkan kesimpulan di atas, saran yang diberikan adalah sebagai berikut:

1. Bagi Sekolah Dasar

Diharapkan dapat meningkatkan dan menghidupkan kembali Juru Pemantau Jentik (JUMANTIK) guna memberantas jentik nyamuk yang ada di lingkungan sekolah, seperti ditempat penampungan air (bak kamar mandi, dan tendon), genangan air dan juga yang memungkinkan menjadi tempat perkembang biakan nyamuk Aedes aegypti.

\section{Bagi Instansi Terkait}

Dinas Pendidikan Kabupaten Sidoarjo dan Dinas Kesehatan Kabupaten Sidoarjo diharapkan membuat prioritas program pemberantasan jentik nyamuk di lingkungan sekolah sehingga dapat menurunkan kejadian demam berdarah dengue. 
3. Bagi Peneliti lain

Disarankan agar menambah variabel sanitasi lingkungan sekolah selain ketersediaan air bersih, saranan pembuangan sampah, dan kepadatan jentik nyamuk, dan mencoba menggunakan metode penelitian studi retrospektif sehingga dapat memperkuat hasil yang diperoleh.

\section{DAFTAR RUJUKAN}

Dinas Kesehatan Kabupaten Sidoarjo. 2016. Laporan Bulanan Penyakit DBD Kabupaten Sidoarjo 2016. Sidoarjo: Dinas Kesehatan Kabupaten Sidoarjo

Dinas Kesehatan Kabupaten Sidoarjo. 2016. Profil Kesehatan Kabupaten Sidoarjo 2015. Sidoarjo: Dinas Kesehatan Kabupaten Sidoarjo

Endy, Timothy P., Chunsuttiwat, Supamit., Nisalak, Ananda., et al. 2002. Epidemiology of Inapparent and Symptomatic Acute Dengue Virus Infection: A Prospective Study of Primary School Children in Kamphaeng Phet, Thailang. American Journal of Epidemiology. 156(1): 40-51

Ginanjar, G. 2014. Demam Berdarah. Yogyakarta: B First.

Haryono., Suyadi., Hakim, Luchman \& Yanuwiadi, Bagyo. 2016. The Role of Environmental and Behavior Factors to Dengue Fever Incidents. Journal of Applied Enviromental and Biological Sciences. 6(4): 1-8

Hasyimi, H., \& Soekino Mardjan. 2004. Pengamatan Tempat Perindukan Aedes aegypti Pada Tempat Penampungan Air Rumah Tangga Pada Masyarakat Pengguna Air Olahan. Jurnal Ekologi Kesehatan. 3(1): 37-42

Kementerian Kesehatan Republik Indonesia. 2011. Modul Pengendalian Demam Berdarah
Dengue. Jakarta: Direktorat Jenderal Pengendalian Penyakit dan Penyehatan Lingkungan

Kementerian Kesehatan Republik Indonesia. 2016. Kendalikan DBD dengan PSN 3 M Plus. (Online) (http://www.depkes.go.id/article/v iew/16020900002/kendalikandbd-dengan-psn-3m-plus.html) diakses pada tanggal 30 Januari 2017

Nurjanah, dkk. 2013. Hubungan Praktik PSN dan Akses Air Bersih dengan Kejadian DBD pada Siswa SD di Kecamatan Palu Selatan. (Online) (http://repository.unhas.ac.id/bitstr eam/handle/123456789/4249/JUR NAL\%20Nurjanah\%20K1110902 3.pdf?sequence $=1$ ) diakses pada tanggal 1 Oktokber 2016

Peraturan Pemerintah Republik Indonesia No. 66 Tahun 2010 tentang Pengelolaan dan Penyelenggaraan Pendidikan

Sholihah, Q. \& Prasetyo, K. 2014. Hubungan Kondisi Sanitasi Lingkungan, Pengetahuan dan Tingkat Pendidikan terhadap

Kejadian Demam Berdarah Dengue (DBD) di Kelurahan Lontar Kecamatan Sambikereb Kota Surabaya. Jurnal Swara Bhumi, 3(3): 219-228

Sucipto, $\quad$ P. T., Raharjo, Mursid \& Nurjazuli. 2015. Faktor-Faktor yang Mempengaruhi Kejadian

Penyakit Demam Berdarah Dengue (DBD) dan Jenis Serotipe Virus Dengue di Kabupaten Semarang. Jurnal Kesehatan Lingkungan Indonesia, 14(2):5156

Suharjo .2006. Mengenal Pendidikan Sekolah Dasar Teori Dan Praktek. Jakarta: Direktorat Jenderal Pendidikan Tinggi.

Suyasa, I. N. G., Putra, N. A. \& Aryanta, R. I. W. 2008. Hubungan Faktor Lingkungan dan Perilaku 
Masyarakat dengan Keberadaan Vektor Demam Berdarah Dengue (DBD) di Wilayah Kerja Puskesmas I Denpasar Selatan. Jurnal Ecotrophic, 3(1):1-6

Wahyuni, Nur Ifka \& Saraswati Dian. 2013. Faktor Risiko Sanitasi Lingkungan Rumah Terhadap Kejadian Penyakit Demam Berdarah Dengue (DBD) di Wilayah Kerja Puskesmas Limboto Kecamatan Limbotokabupaten Gorontalo Tahun 2013. Jurnal Kim Fakultas Ilmu-Ilmu Kesehatan Dan Keolahragaan. 1(1)

Wati, Fatna Andika. 2010. Pengaruh Air Perasan Kulit Jeruk Manis (Citrus aurantium sub spesies sinensis) terhadap Tingkat
Kematian Larva Aedes aegypti Instar Iii In Vitro. (Online) (https://eprints.uns.ac.id/6884/1/ 178802511201104181.pdf) diakses pada tanggal 10 Januari 2017

Wati, W. E. 2009. Beberapa faktor yang Berhubungan dengan Kejadian Demam Berdarah Dengue (DBD) di Kelurahan Ploso Kecamatan Pacitan Tahun 2009. Skripsi.

Surakarta: Fakultas Ilmu Kesehatan Universitas Muhammadiyah Surakarta

World Health Organization. 2002. Pencegahan dan Pengendalian Dengue dan Demam Berdarah Dengue: Panduan. Terjemahan Palupi Widyastuti. 2004. Jakarta: EDC. 